\title{
Protective effects of Ligustrum lucidum fruit extract on acute butylated hydroxytoluene-induced oxidative stress in rats
}

\author{
H.M. Lin ${ }^{\text {a, }}$, F.L. Yen ${ }^{\text {c, } 1}$, L.T. Ng ${ }^{\text {b }}$, C.C Lin ${ }^{\mathrm{d}, *}$ \\ a Graduate Institute of Natural Products, College of Pharmacy, Kaohsiung Medical University, Kaohsiung, Taiwan \\ ${ }^{\mathrm{b}}$ Department of Biotechnology, Tajen University, Pingtung, Taiwan \\ ${ }^{\mathrm{c}}$ Graduate Institute of Pharmaceutical Sciences, College of Pharmacy, \\ Kaohsiung Medical University, Kaohsiung, Taiwan \\ ${ }^{\mathrm{d}}$ Faculty of Pharmacy, College of Pharmacy, Kaohsiung Medical University, Kaohsiung, Taiwan \\ Received 24 May 2006; received in revised form 31 October 2006; accepted 2 November 2006 \\ Available online 10 November 2006
}

\begin{abstract}
Nuzhenzi, the fruit of Ligustrum lucidum Ait. (Oleaceae), is commonly used as tonic for kidney and liver in the traditional Chinese medicine prescription. The present study aimed to investigate the antioxidant activities of ethanol extract of Ligustrum lucidum fruits (ELL) and its effects on butylated hydroxytoluene (BHT)-induced oxidative stress in rats. Results showed that ELL possesses weak antioxidant activities. Compared to the BHT $(1000 \mathrm{mg} / \mathrm{kg})$-treated group, results showed that ELL at 250,500 and $1000 \mathrm{mg} / \mathrm{kg}$ significantly reduced the levels of blood urea nitrogen (BUN), serum glutamic pyruvic transaminase (sGPT), glutamic oxaloacetic transaminase (sGOT), alkaline phosphatase (sALP), lactate dehydrogenase (LDH), triglyceride (TG) and creatinine (Cr), as well as LDH in bronchoalveolar lavage fluid (BALF). It also significantly decreased the level of lipid peroxides in liver and lung. In addition, ELL significantly enhanced the levels of catalase (CAT), superoxide dismutase (SOD) and glutathione peroxidase $(\mathrm{GPx})$ in these organs. Histopathological evaluation of the tissues revealed that ELL reduced the incidence of lung lesions, while the liver and kidney tissues were not affected by BHT administration. Taken together, the protective effect of ELL against acute BHT-induced oxidative stress in rats could be through the upregulation of antioxidant enzymes.
\end{abstract}

(C) 2006 Elsevier Ireland Ltd. All rights reserved.

Keywords: Ligustrum lucidum; Butylated hydroxytoluene; Antioxidant enzymes; Oxidative stress

\section{Introduction}

Nuzhenzi, the fruit of Ligustrum lucidum Ait. (Oleaceae), is well known as tonic for kidney and liver in the traditional Chinese medicine prescription (Shi et al., 1998). It was reported to possess immunomodulatory, anti-inflammatory, hepatoprotective, anti-tumor and anti-aging activities (He et al., 2001a). Ethanol extract of Ligustrum lucidum fruits and its secoiridoid glucosides, namely oleoside dimethylester, oleuropein, neonuezhenide, lucidumoside $\mathrm{B}$ and lucidumoside $\mathrm{C}$, were shown to inhibit the free radical induced hemolysis in red blood cells (He et al., 2001b). Oleuropein also exhibited antiviral activities against respiratory syncytial virus (RSV) and parainfluenza

\footnotetext{
* Corresponding author. Tel.: +886 $73121101 \times 2122$; fax: +886 73135215 E-mail address: aalin@kmu.edu.tw (C.C Lin).

1 These authors contributed equally to this work.
}

type 3 virus (Para 3), whereas oleoside dimethylester, lucidumoside $\mathrm{C}$ and ligustroside were active against Para 3 virus (Ma et al., 2001). ELL contains a large amount of oleanolic acid and ursolic acid, which have been demonstrated to be effective in treating inflammation, hepatotoxicity, pain and hyperlipidermic (Yim et al., 2001; Liu et al., 2003).

Butylated hydroxytoluene (BHT), a phenolic antioxidant, is generally recognized as safe food additive and preservative (Lanigan and Yamarik, 2002). However, when at high doses it is known to cause lactate dehydrogenase (LDH), serum glutamic pyruvic transaminase (sGPT) and glutamic oxaloacetic transaminase (sGOT) leakage, which consequently lead to pneumotoxicity, hepatotoxicity and nephrotoxicity in animals (Marino and Mitchell, 1972; Powell and Connolly, 1991; Reed et al., 2001). BHT-quinone methide (BHT-QM; 2,6-di-tert-butyl-4-methylene-cyclohexa-2,5-dienone), an intermediate metabolite of BHT, is metabolized by cytochrome $\mathrm{P} 450$ in liver and lung in mice (Witschi et al., 1989). 
An overproduction of BHT-QM can covalently bind to protein and nucleic acid, which consequently lead to acute hepatotoxicity and pneumotoxicity. In normal condition, BHT-QM is conjugated and detoxicated by glutathione (GSH), but excess of BHT-QM can enhance the oxidative stress and deplete GSH (Mizutani et al., 1984; Sun et al., 2003). Oxidative stress is considered to play an important role in the cause of many diseases, including inflammation, aging and cancer (Cerutti, 1985; Lavrovsky et al., 2000).

Besides being regularly use as tonic in the traditional Chinese medicine, fruits of Ligustrum lucidum also possess the potential of developing into other health products. Hence, in this study, our aim was to examine the antioxidant activities of ELL and its pharmacological effects on BHT-induced acute oxidative stress in rats.

\section{Materials and methods}

\subsection{Chemicals}

Butylated hydroxytoluene (BHT), Tris- $\mathrm{HCl}$, thiobarbituric acid (TBA), ferrous chloride, ascorbate, xanthine, xanthine oxidase, ethylenediaminetetraacetic acid (EDTA), nitroblue tetrazolium (NBT) and 5,5'-dithio(bis)2-nitrobenzoic acid (DTNB) were purchased from Sigma Chemicals Co. (St. Louis, MO, USA). All other chemicals and reagents used were of analytical grade.

\subsection{Preparation of plant extract}

Fruits of Ligustrum lucidum were obtained from the traditional Chinese pharmacy in Kaohsiung (Taiwan). It was then authenticated by Professor C.C. Lin, Kaohsiung Medical University, Taiwan. To prepare the Ligustrum lucidum extract, $100 \mathrm{~g}$ of Ligustrum lucidum fruits was thoroughly powdered and then extracted with $500 \mathrm{ml}$ of $95 \%$ ethanol for $3 \mathrm{~h}$ in the hot water bath. After the supernatant of the first extraction was removed, an additional $500 \mathrm{ml}$ of $95 \%$ ethanol was added, the sample was further subjected to another $3 \mathrm{~h}$ of extraction. The same procedure was repeated for three times. The decoction obtained from the three separate extractions was mixed, filtered, concentrated and lyophilized. The yield of dried Ligustrum lucidum fruit extract (ELL) was about $20 \%$, which was collected and stored at $-21{ }^{\circ} \mathrm{C}$ until use.

\subsection{Free radical scavenging activity assay}

Free radical scavenging activity was assayed spectrophotometrically by the reduction of cytochrome $c$ method as described by McCord and Fridovich (1969).

\subsection{Xanthine oxidase inhibition test}

Xanthine oxidase inhibition activity was estimated by the formation of uric acid from xanthine-xanthine oxidase system (Chang et al., 1994).

\subsection{Anti-lipid peroxidation assay}

The effect of ELL on rat liver homogenate induced with $\mathrm{FeCl}_{2}$-ascorbic acid for lipid peroxidation was determined by malondialdehyde-thiobarbituric acid (MDA-TBA) adduct according to Ohkawa et al. (1979).

\subsection{Animals}

Male Wistar rats, age at 6 weeks old, were purchased from the National Laboratory of Animal Breeding and Research Center (Taipei, Taiwan). They were housed in a controlled environment with temperature maintained at $22 \pm 3{ }^{\circ} \mathrm{C}$ and humidity at $55 \pm 5 \%$ under a $12: 12 \mathrm{~h} \mathrm{light/dark} \mathrm{cycle.} \mathrm{Animals} \mathrm{were} \mathrm{fed}$ a standard laboratory diet and tap water ad libitum. After a week of adaptation, animals were subjected to various treatments for BHT-induced studies. All experimental protocols were performed according to the Guide for the Care and Use of Laboratory Animals (National Institutes of Health, publication No. 86-23, revised 1985).

\subsection{Animal treatments}

The experiment was carried out according to procedures as described by Nakagawa et al. (1984) with minor modification. In brief, animals were randomly divided into five groups of nine animals each, namely group A: vehicle control; group B: BHTtreated; group C: BHT + ELL $250 \mathrm{mg} / \mathrm{kg}$; group D: BHT + ELL $500 \mathrm{mg} / \mathrm{kg}$ and group E: BHT + ELL $1000 \mathrm{mg} / \mathrm{kg}$. Groups A and $\mathrm{B}$ were orally given $10 \mathrm{ml} / \mathrm{kg}$ of distilled water for 7 days, while other groups were intragastrically administered with different doses of ELL. At the end of the 7th day, $1000 \mathrm{mg} / \mathrm{kg}$ of BHT dissolving in olive oil was given to groups B, C, D and E by gavage $6 \mathrm{~h}$ after the extracts were administered. At the same time, rats in group A were administrated with the same volume of olive oil. All animals were anesthetized with ether and sacrificed $18 \mathrm{~h}$ later. The thorax was opened by a median incision and the trachea was cannulated with a plastic catheter attached to a $10 \mathrm{ml}$ syringe. The bronchoalveolar lavage fluid (BALF) was obtained by washing the lung across the trachea with $10 \mathrm{ml}$ saline. It was then centrifuged at $300 \times g$ at $4{ }^{\circ} \mathrm{C}$ for $10 \mathrm{~min}$ to obtain the supernatant for biochemical assays. Blood samples were collected for biochemical studies. The liver, lung and kidney were dissected and sectioned for histopathological observations. Part of these tissues were collected and stored at $-80^{\circ} \mathrm{C}$ until use for biochemical assays.

\subsection{Serum and bronchoalveolar lavage fluid (BALF) assessment}

Blood collected was centrifuged at $1600 \times g$ at $4{ }^{\circ} \mathrm{C}$ for 15 min to obtain the serum, which was then subjected to serum glutamic pyruvic transaminase (sGPT), glutamic oxaloacetic transaminase (sGOT), alkaline phosphatase (sALP), lactate dehydrogenase (LDH), blood urea nitrogen (BUN), creatinine $(\mathrm{Cr})$, cholesterol and triglyceride (TG) analyses. LDH in BALF were also measured. These analyses were carried out according 
to the manufacturer's procedures using a Hitachi 7050 autoanalyser with commercial kits.

\subsection{Analysis of tissue homogenates}

Liver, lung and kidney tissues were homogenized in four volumes of ice-cold $150 \mathrm{mM}$ Tris- $\mathrm{HCl}(\mathrm{pH} 7.4)$ using PotterElvehjem homogenizer. The homogenates were centrifuged at $1600 \times g$ for $15 \mathrm{~min}$ at $4{ }^{\circ} \mathrm{C}$ to obtain a supernatant for various biochemical analyses. Catalase (CAT) activity was determined according to Aebi (1984). Superoxide dismutase (SOD) activity was determined by the method of Beauchamp and Fridovich (1971). Total glutathione peroxidase (GPx) was done with method of Flohe and Gunzler (1984). Lipid peroxidation in the liver, kidney and lung homogenates was ascertained by the formation of malondialdehyde (MDA) and measured by the thiobarbituric acid reactive method according to Ohkawa et al. (1979). The protein concentration was measured by the method of Lowry et al. (1951).

\subsection{Histopathological examinations}

The liver, lung and kidney were fixed in $10 \%$ neutral buffered formalin, dehydrated with 50-100\% ethanol solutions, and then embedded in paraffin. Tissues were sectioned at thickness $5 \mu \mathrm{m}$, followed by staining with haematoxylin-eosin dye before subjecting to photomicroscopic observation.

\subsection{Statistical analysis}

All experimental data were expressed as means \pm standard deviations (S.D.) of nine analyses. Statistical analysis was per- formed by one-way analysis of variance (ANOVA), followed by Tukey's multiple range tests. A probability value of $P<0.05$ was considered as significantly difference.

\section{Results}

\subsection{Antioxidant activities of ELL}

In the cytochrome c assay, the scavenging effect of ELL on the superoxide anions was found to increase with increasing sample concentrations. A concentrations $0.1-3.0 \mathrm{mg} / \mathrm{ml}$, ELL showed a scavenging rate ranging from $26.39-77.78 \%$. Its $\mathrm{IC}_{50}$ value was $1.58 \mathrm{mg} / \mathrm{ml}$.

In the xanthine oxidase inhibition test, ELL demonstrated an inhibitory effect on xanthine oxidase activity in a concentrationdependent manner. The inhibitory activity of ELL at $1-10 \mathrm{mg} / \mathrm{ml}$ ranged from $24.22-59.45 \%$. Its $\mathrm{IC}_{50}$ value was $7.54 \mathrm{mg} / \mathrm{ml}$.

In anti-lipid peroxidation assay, the inhibition of MDA formation in rat liver homogenate increased with increasing concentration of ELL. At concentrations $1-10 \mathrm{mg} / \mathrm{ml}$, the anti-lipid peroxidation activity ranged from $31.82-72.39 \%$, with an $\mathrm{IC}_{50}$ value of $4.64 \mathrm{mg} / \mathrm{ml}$.

\subsection{Effects of ELL on the levels of sGPT, sGOT, sALP, $B U N, C r$, LDH, cholesterol and TG, and BALF LDH in BHT-treated rats}

Compared to the control group, results showed that, with the exception of cholesterol, the levels of sGPT, sGOT, sALP, BUN, $\mathrm{Cr}$, LDH, TG, and BALF LDH were significantly increased in rats with oxidative stress induced by BHT (Tables 1 and 2). Preadministration of ELL at 250, 500 and $1000 \mathrm{mg} / \mathrm{kg}$ significantly

Table 1

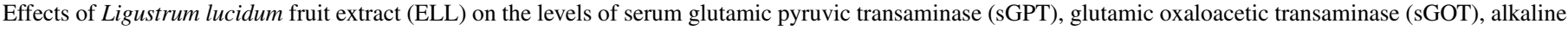
phosphatase (sALP), lactate dehydrogenase (LDH) and creatinine $(\mathrm{Cr})$, and blood urea nitrogen (BUN) in rats with oxidative stress induced by BHT

\begin{tabular}{|c|c|c|c|c|c|}
\hline Treatment & sGPT (U/1) & sGOT (U/1) & sAlP (U/1) & $\mathrm{BUN}(\mathrm{mg} / \mathrm{dl})$ & $\mathrm{Cr}(\mathrm{mg} / \mathrm{dl})$ \\
\hline Control & $45.0 \pm 2.2$ & $115.1 \pm 14.0$ & $336.7 \pm 16.6$ & $14.79 \pm 2.64$ & $0.462 \pm 0.030$ \\
\hline BHT & $65.6 \pm 17.1^{\mathrm{a}}$ & $190.2 \pm 50.3^{a}$ & $692.3 \pm 74.1^{\mathrm{a}}$ & $22.64 \pm 2.69^{\mathrm{a}}$ & $0.646 \pm 0.052^{\mathrm{a}}$ \\
\hline $\mathrm{BHT}+\mathrm{ELL}(250 \mathrm{mg} / \mathrm{kg})$ & $52.1 \pm 8.1^{\mathrm{b}}$ & $126.9 \pm 11.3^{b}$ & $551.1 \pm 37.5^{\mathrm{bc}}$ & $22.06 \pm 2.88^{c}$ & $0.564 \pm 0.036^{\mathrm{bc}}$ \\
\hline $\mathrm{BHT}+\mathrm{ELL}(500 \mathrm{mg} / \mathrm{kg})$ & $50.0 \pm 6.5^{\mathrm{b}}$ & $121.2 \pm 13.6^{\mathrm{b}}$ & $546.6 \pm 75.4^{\mathrm{bc}}$ & $21.50 \pm 1.28^{c}$ & $0.564 \pm 0.032^{\mathrm{bc}}$ \\
\hline $\mathrm{BHT}+\mathrm{ELL}(1000 \mathrm{mg} / \mathrm{kg})$ & $48.1 \pm 4.3^{\mathrm{b}}$ & $113.3 \pm 8.1^{\mathrm{b}}$ & $529.2 \pm 58.9^{\mathrm{bc}}$ & $19.36 \pm 1.62^{\mathrm{bc}}$ & $0.565 \pm 0.043^{\mathrm{bc}}$ \\
\hline
\end{tabular}

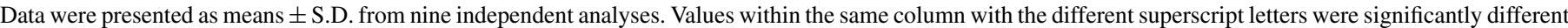

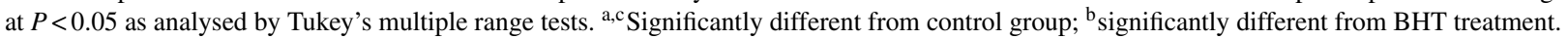

Table 2

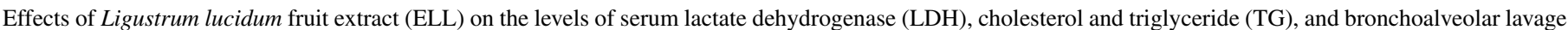
fluid (BALF) LDH in rats with oxidative stress induced by BHT

\begin{tabular}{|c|c|c|c|c|}
\hline \multirow[b]{2}{*}{ Treatment } & \multicolumn{3}{|l|}{ Serum } & \multirow{2}{*}{$\frac{\mathrm{BALF}}{\log \mathrm{LDH}(\mathrm{U} / \mathrm{l})}$} \\
\hline & $\log \mathrm{LDH}(\mathrm{U} / \mathrm{l})$ & Cholesterol (mg/dl) & $\log \mathrm{TG}(\mathrm{mg} / \mathrm{dl})$ & \\
\hline Control & $2.77 \pm 0.25$ & $64.86 \pm 9.99$ & $1.80 \pm 0.06$ & $1.55 \pm 0.14$ \\
\hline BHT & $3.27 \pm 0.02^{\mathrm{a}}$ & $75.89 \pm 12.97$ & $2.30 \pm 0.14^{\mathrm{a}}$ & $1.72 \pm 0.30^{\mathrm{a}}$ \\
\hline BHT + ELL (250 mg/kg) & $3.06 \pm 0.08^{b c}$ & $68.00 \pm 10.63$ & $1.86 \pm 0.30^{\mathrm{b}}$ & $1.62 \pm 0.11^{\mathrm{b}}$ \\
\hline $\mathrm{BHT}+\mathrm{ELL}(500 \mathrm{mg} / \mathrm{kg})$ & $2.98 \pm 0.09^{\mathrm{b}}$ & $67.00 \pm 8.51$ & $1.82 \pm 0.15^{\mathrm{b}}$ & $1.59 \pm 0.10^{\mathrm{b}}$ \\
\hline $\mathrm{BHT}+\mathrm{ELL}(1000 \mathrm{mg} / \mathrm{kg})$ & $2.90 \pm 0.06^{\mathrm{b}}$ & $61.44 \pm 8.25^{\mathrm{b}}$ & $1.78 \pm 0.30^{\mathrm{b}}$ & $1.55 \pm 0.07^{b}$ \\
\hline
\end{tabular}

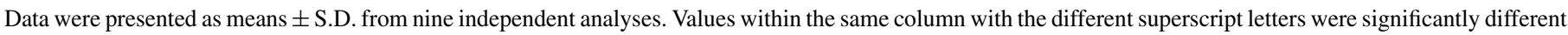
at $P<0.05$ as analysed by Tukey's multiple range tests. ${ }^{\text {a,c }}$ Significantly different from control group; ${ }^{\mathrm{b}}$ significantly different from BHT treatment. 
Table 3

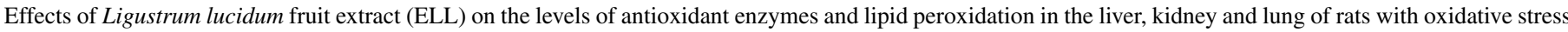
induced by BHT

\begin{tabular}{|c|c|c|c|c|c|}
\hline Treatment & Control & BHT & $\mathrm{BHT}+\mathrm{ELL}(250 \mathrm{mg} / \mathrm{kg})$ & $\mathrm{BHT}+\mathrm{ELL}(500 \mathrm{mg} / \mathrm{kg})$ & $\mathrm{BHT}+\mathrm{ELL}(1000 \mathrm{mg} / \mathrm{kg})$ \\
\hline \multicolumn{6}{|c|}{$\log$ MDA (nmol/g protein) } \\
\hline Liver & $2.74 \pm 0.20$ & $2.59 \pm 0.25$ & $2.12 \pm 0.22^{\mathrm{bc}}$ & $2.03 \pm 0.37^{\mathrm{bc}}$ & $1.91 \pm 0.43^{\mathrm{bc}}$ \\
\hline Kidney & $2.85 \pm 0.14$ & $2.70 \pm 0.18$ & $2.26 \pm 0.69 \mathrm{c}$ & $2.42 \pm 0.23$ & $2.27 \pm 0.35^{\mathrm{c}}$ \\
\hline Lung & $2.86 \pm 0.09$ & $3.06 \pm 0.15^{\mathrm{a}}$ & $2.93 \pm 0.09$ & $2.88 \pm 0.12$ & $2.88 \pm 0.19^{b}$ \\
\hline \multicolumn{6}{|c|}{ SOD (U/mg protein) } \\
\hline Liver & $7.34 \pm 1.23$ & $5.32 \pm 0.77^{\mathrm{a}}$ & $6.77 \pm 1.23$ & $7.98 \pm 0.85^{\mathrm{b}}$ & $8.02 \pm 1.61^{\mathrm{b}}$ \\
\hline Kidney & $8.71 \pm 1.19$ & $6.13 \pm 1.14^{\mathrm{a}}$ & $6.49 \pm 0.90^{\mathrm{cd}}$ & $6.31 \pm 1.44^{\mathrm{ce}}$ & $9.29 \pm 0.76^{\text {bde }}$ \\
\hline Lung & $2.05 \pm 0.53^{\mathrm{a}}$ & $0.94 \pm 0.31^{\mathrm{a}}$ & $1.45 \pm 0.30^{\mathrm{c}}$ & $1.55 \pm 0.38^{\mathrm{b}}$ & $1.88 \pm 0.41^{\mathrm{b}}$ \\
\hline \multicolumn{6}{|c|}{ CAT (U/mg protein) } \\
\hline Liver & $1002.92 \pm 186.44$ & $815.94 \pm 88.17^{\mathrm{a}}$ & $1124.80 \pm 193.34^{\mathrm{b}}$ & $1364.92 \pm 272.78^{b c}$ & $1578.48 \pm 276.39^{\mathrm{bc}}$ \\
\hline Kidney & $144.06 \pm 27.92$ & $78.71 \pm 12.21^{\mathrm{a}}$ & $123.17 \pm 27.88^{\mathrm{d}}$ & $137.70 \pm 32.11^{\text {be }}$ & $218.24 \pm 75.46^{\text {bcde }}$ \\
\hline Lung & $485.87 \pm 44.28$ & $348.99 \pm 56.88^{a}$ & $434.65 \pm 82.93$ & $517.58 \pm 146.39^{b}$ & $539.27 \pm 90.88^{b}$ \\
\hline \multicolumn{6}{|c|}{ GPx (U/mg protein) } \\
\hline Liver & $3.64 \pm 0.21$ & $2.70 \pm 0.43^{\mathrm{a}}$ & $2.66 \pm 0.50^{\mathrm{c}}$ & $3.26 \pm 0.44^{\mathrm{d}}$ & $3.52 \pm 0.45^{\mathrm{bd}}$ \\
\hline Kidney & $2.99 \pm 0.25$ & $1.83 \pm 0.34^{\mathrm{a}}$ & $2.48 \pm 0.44$ & $2.87 \pm 0.91^{b}$ & $3.10 \pm 0.43^{b}$ \\
\hline Lung & $1.32 \pm 0.16$ & $0.99 \pm 0.29^{\mathrm{a}}$ & $1.52 \pm 0.18^{\mathrm{bd}}$ & $1.53 \pm 0.09^{\text {be }}$ & $1.86 \pm 0.13^{\text {bcde }}$ \\
\hline
\end{tabular}

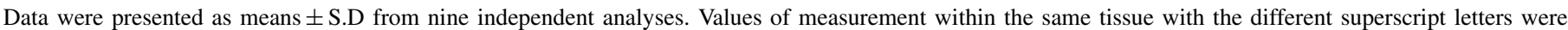

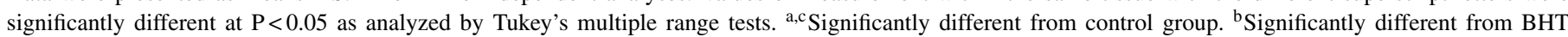
treatment. ${ }^{\text {d,e }}$ Significantly different from BHT treated with ELL group.

inhibited the BHT-induced increase in the levels of these biomolecules. No difference was noted in BUN and cholesterol levels between BHT alone and BHT plus ELL at 250 and $500 \mathrm{mg} / \mathrm{kg}$. However, a significant decrease in these two components was noted at $1000 \mathrm{mg} / \mathrm{kg}$ ELL.

\subsection{Effects of ELL on the levels of antioxidant enzymes in tissues of BHT-treated rats}

BHT administration significantly decreased the levels of SOD, CAT and GPx in liver, kidney and lung (Table 3). Pre-treatment with ELL significantly enhanced the activity of these antioxidant enzymes. Interestingly, administration of $1000 \mathrm{mg} / \mathrm{kg}$ ELL increased the SOD level in all tested tissues to that of the control group, whereas the levels of CAT and GPx were found to return to the level of control group at 500 and $1000 \mathrm{mg} / \mathrm{kg}$ ELL.

\subsection{Effect of ELL on the level of MDA in tissues of BHT-treated rats}

Compared to the control group, BHT at $1000 \mathrm{mg} / \mathrm{kg}$ significantly increased the level of MDA in lung tissue, while the level in the liver and kidney was not affected (Table 3). Pre-treatment with ELL at 500 and $1000 \mathrm{mg} / \mathrm{kg}$ reversed the MDA concentration to the normal level in lung. Compared to the BHT-treated group, administration of 250, 500 and $1000 \mathrm{mg} / \mathrm{kg}$ ELL significantly decreased the MDA level in liver, while the level in the kidney was moderately affected.

\subsection{Histopathological observation}

Histopathological results showed that BHT at $1000 \mathrm{mg} / \mathrm{kg}$ caused a significant damage in lung as indicated by a serious change in the tissue appearance, with inflammation and structure destruction in the tissue as compared with the control group (Fig. 1). However, liver and kidney tissues were not affected (Figs. 2 and 3). Interestingly, pre-treatment with ELL significantly reversed the lung condition in the BHT-treated rats.

\section{Discussion}

The present study demonstrated that ELL possesses weak antioxidant activities, but shows effective protection against BHT-induced oxidative damage in rats. This observation can be supported by the significant decrease in the levels of sGPT, sGOT, sALP, BUN, Cr, LDH and TG, and BALF LDH. Besides decreasing the level of lipid peroxides in liver and lung, pretreatment of ELL led to an increase in CAT, SOD and GPx levels in these organs in BHT-treated rats. The histopathological observation also revealed that ELL could reduce the incidence of lung lesions. These results support that ELL could have protective effect against acute BHT-induced oxidative stress in rats, its mechanism of action could be through the enhancement of antioxidant enzymes production.

Oxidant-induced injury to the plasma membrane of cells can evoke a wide variety of responses. Biological membranes contain a large amount of polyunsaturated fatty acids, which are particularly susceptible to peroxidative attacks to produce lipid peroxides. Lipid peroxides have been used as a sensitive indicator of oxidant-induced cell injury (Hickey et al., 2001). In this study, we showed that BHT at $1000 \mathrm{mg} / \mathrm{kg}$ significantly increased the level of lipid peroxides and caused serious histological lesion to the lung tissue. Surprisingly, no obvious changes were noted in the liver and kidney tissues. This could be due to the variation in the metabolic stage and duration of being exposed to BHT or BHT-QM. 


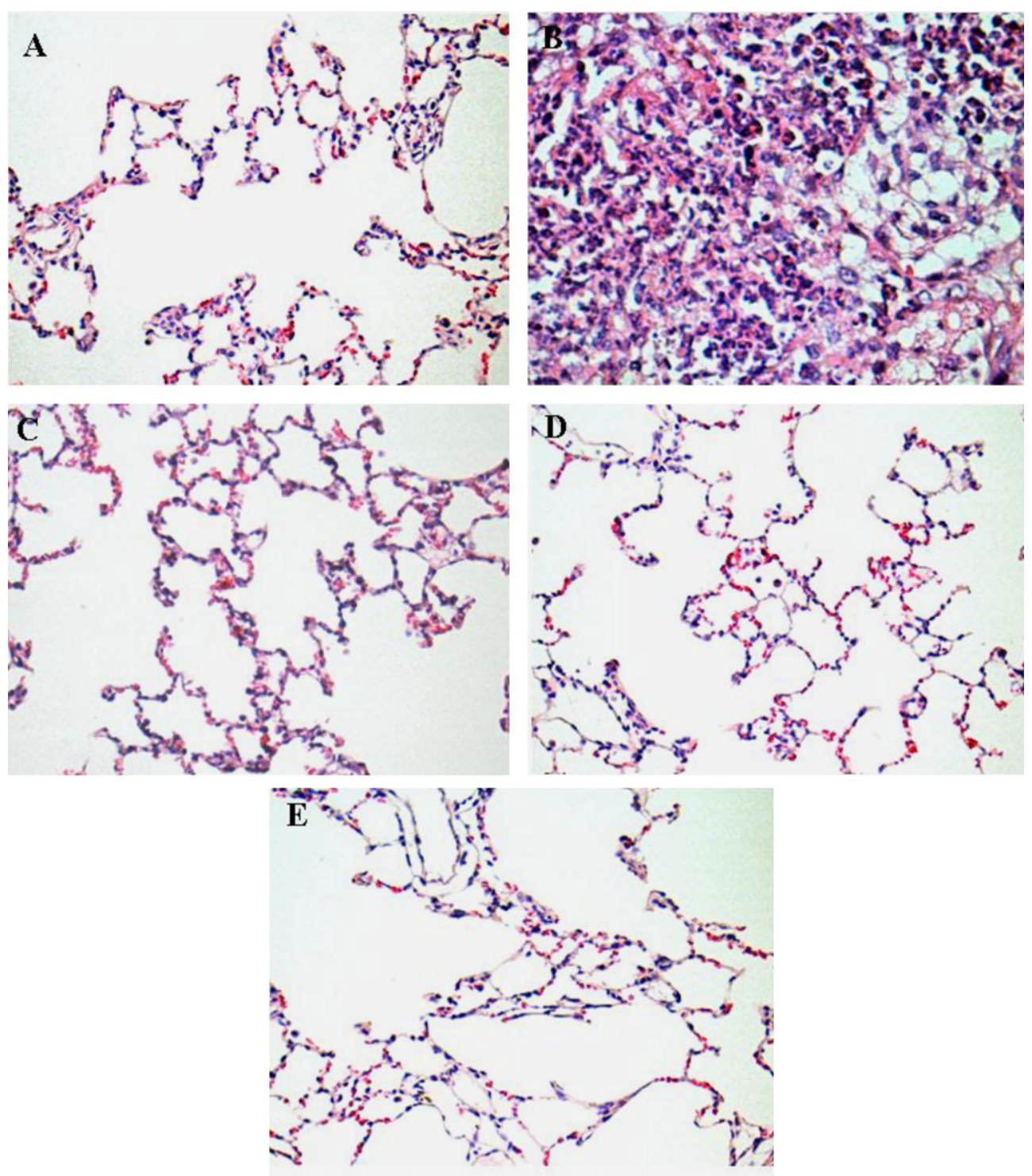

Fig. 1. Effect of Ligustrum lucidum fruit extract (ELL) on acute BHT-induced oxidative stress in the lung of rats. Lung sections were stained with haematoxylin and eosin (H\&E-stained × 200). (A) Control; (B) BHT-treated; (C) BHT + ELL (250 mg/kg); (D) BHT + ELL (500 mg/kg); (E) BHT + ELL (1000 mg/kg).

Hepatic cells participate in a variety of metabolic activities and contain a number of enzymes. In the stage of liver injury, the transport function of hepatocytes is disturbed, which can result in the leakage of plasma membrane, thereby causing an increase in sGPT and sGOT levels. In addition, a defective excretion of bile by the liver was reflected by an increase in the level of sALP. The distribution of LDH throughout the body is also recognized as one of the markers for liver and muscle lesions (Rajesh and Latha, 2004; Yanardag and Tunali, 2006). In this study, the increase in sGPT, sGOT, sALP and LDH levels indicated that BHT could induce hepatic dysfunction. ELL showed protective effect against BHT-induced hepatic dysfunction through decreasing the levels of sGPT, sGOT, sALP and $\mathrm{LDH}$.

The present study also showed that BHT significantly increased the level of LDH in BALF, which was associated with the incidence of lung lesions in BHT-treated rats. It is interesting to note that pre-treatment with ELL was able to protect against BHT-induced lung injury. This can be shown by a decrease in the level of LDH and the alleviation lung tissue damage.

In general, changes in $\mathrm{Cr}$ concentration were more prominent than the level of BUN during the earlier phases of kidney disease (Erdem et al., 2000). BUN only begins to rise after a marked renal parenchyma injury occurs. In this study, the increase in the level of $\mathrm{Cr}$ and BUN indicated that BHT could induce renal dysfunction, which was alleviated by pre-treatment with ELL as shown by a decrease in $\mathrm{Cr}$ and BUN levels. This suggests that ELL may possess protective effect against BHT-induced renal dysfunction.

Hyperlipidemia is considered as an important risk factor of atherosclerosis due to impairment of endothelial function. This is resulted from the reduction of nitric oxide availability and an increase in the production of oxygen free radicals (Bartus et al., 2005). In addition, changes in the enzymatic antioxidative defense systems such as SOD, CAT, GPx and GSH 

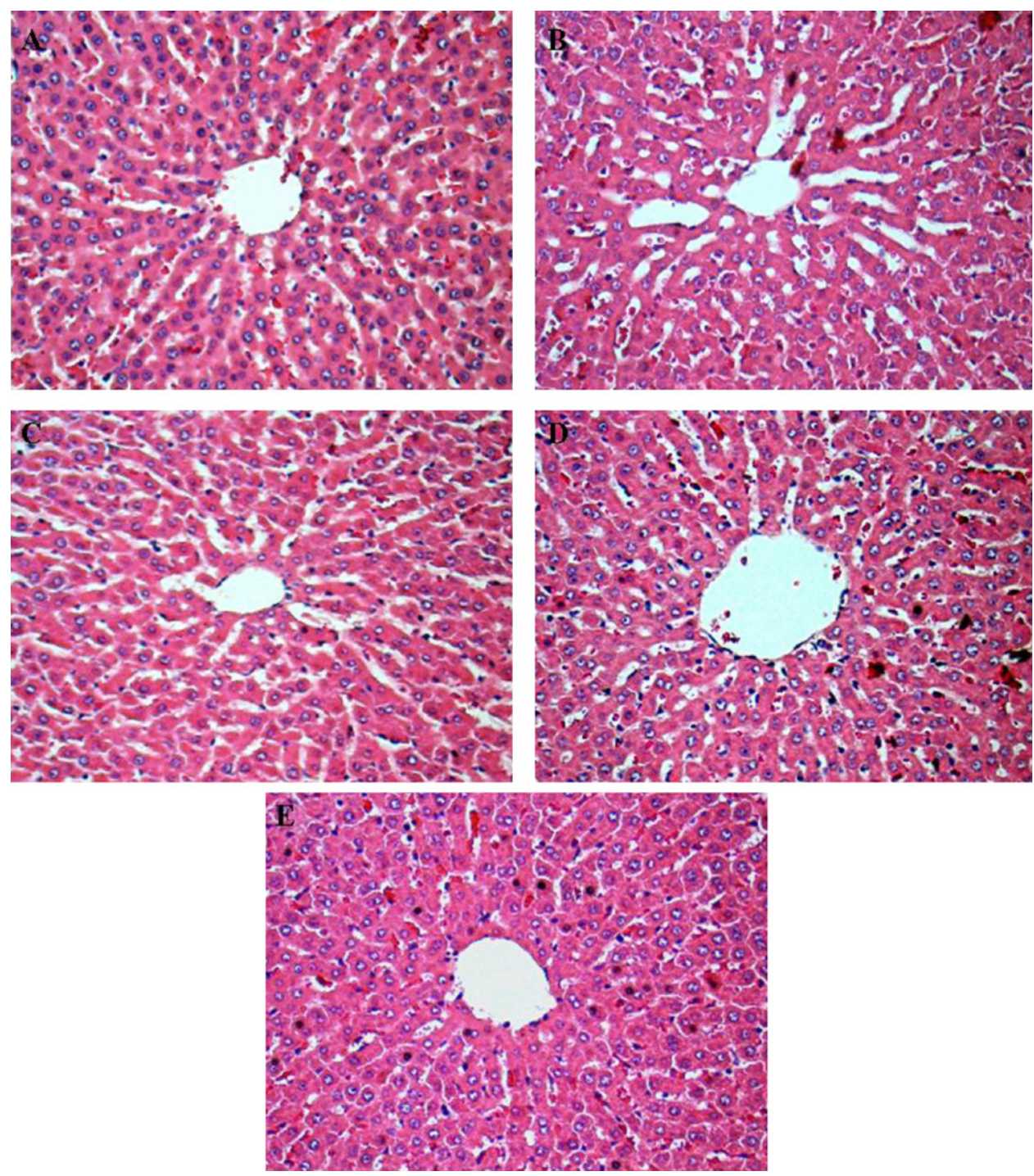

Fig. 2. Effect of Ligustrum lucidum fruit extract (ELL) on acute BHT-induced oxidative stress in the liver of rats. Liver sections were stained with haematoxylin and eosin (H\&E-stained × 200). (A) Control; (B) BHT-treated; (C) BHT + ELL (250 mg/kg); (D) BHT + ELL (500 mg/kg); (E) BHT + ELL (1000 mg/kg).

during hyperlipidemia, also suggest a reduced resistance to reactive oxidant-mediated damage (Oh et al., 2006). An increase in the level of serum TG indicated that BHT might induce the risk of atherosclerosis development. Pre-administration of ELL significantly decrease the levels of serum TG and cholesterol, suggesting ELL might play a role in protecting against atherosclerosis development.

The endogenous antioxidant enzymes are responsible for the detoxification of deleterious oxygen radicals. CAT is a hemoprotein which catalyses the reduction of hydrogen peroxide and protects the tissues from highly reactive hydroxyl radicals (Rajasekaran et al., 2005). SOD constitutes an important link in the biological defense mechanism through dismutation of endogenous cytotoxic superoxide radicals to $\mathrm{H}_{2} \mathrm{O}_{2}$ (Hassan, 1988). GPx plays an important role in the reduction of $\mathrm{H}_{2} \mathrm{O}_{2}$ in the presence of reduced GSH. The detoxifying action of GPx against $\mathrm{H}_{2} \mathrm{O}_{2}$ protects cell membrane against oxidative damage (Jung et al., 2005). The antioxidant enzymes CAT and
GPx protect SOD against inactivation by $\mathrm{H}_{2} \mathrm{O}_{2}$. Reciprocally, SOD protects CAT and GPx against superoxide anion. Thus, the balance of these enzymatic systems is essential to dispose the superoxide anion and peroxides generated in the tissues (Selvakumar et al., 2004). The reduction in the activities of these enzymes and increase in lipid peroxides could reflect the adverse effects of BHT in the antioxidant system in liver, kidney and lung. After ELL treatment, a significant increase in the levels of these antioxidant enzymes with a corresponding decrease in the level of lipid peroxides in the liver, kidney and lung. This finding supports the protective effect of ELL against BHT-induced oxidative stress.

In conclusion, ELL treatment could prevent the acute BHTinduced oxidative stress in rats as demonstrated by the decrease in sGPT, sGOT, sALP and LDH concentrations, and BALF $\mathrm{LDH}$, as well as an increase in levels of antioxidant enzymes in liver, kidney and lung. ELL also effectively protected against lung injury in the BHT-treated rats, which was further supported 

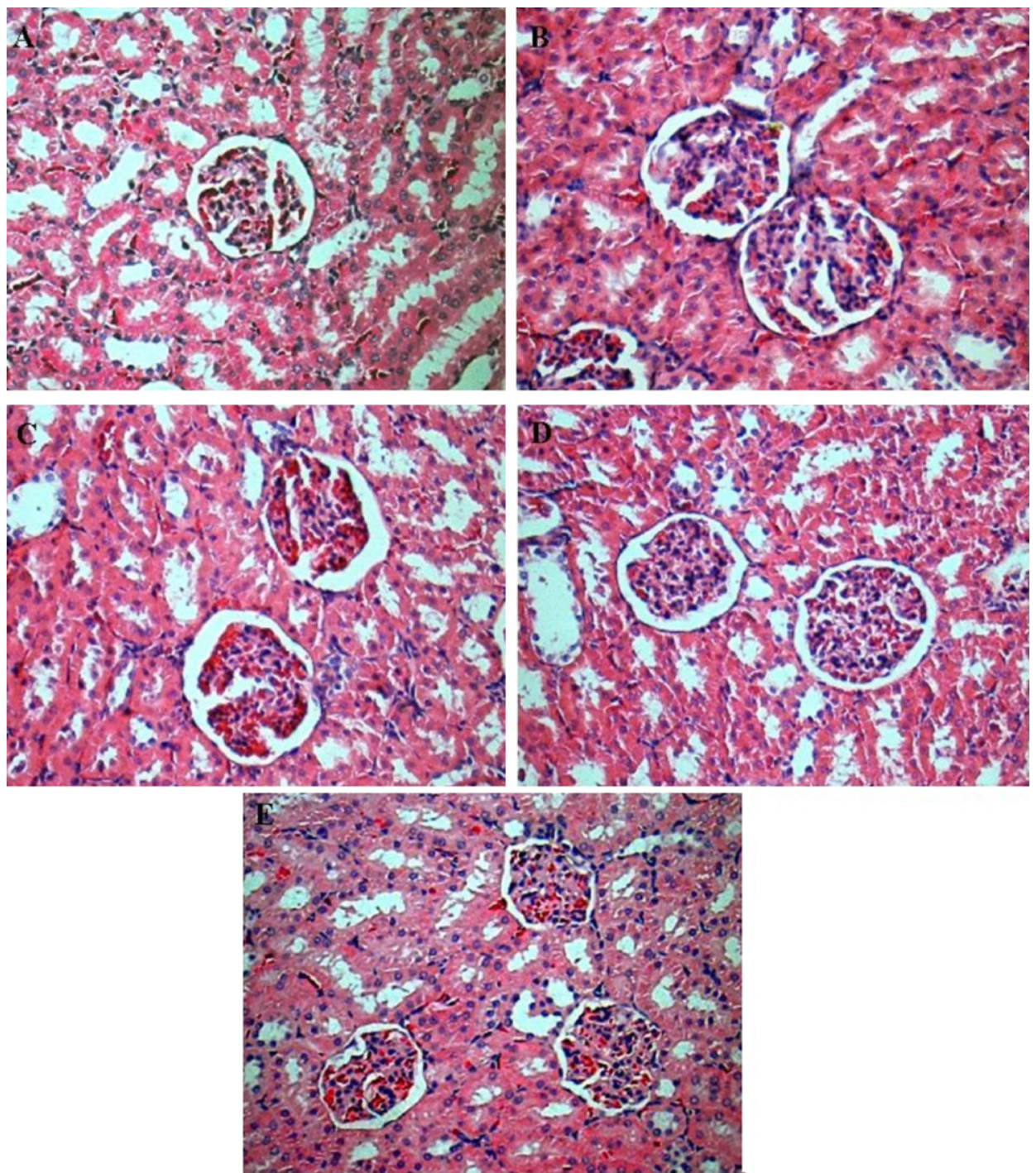

Fig. 3. Effect of Ligustrum lucidum fruit extract (ELL) on acute BHT-induced oxidative stress in the kidney of rats. Kidney sections were stained with haematoxylin and eosin (H\&E-stained $\times 200)$. (A) Control; (B) BHT-treated; (C) BHT + ELL (250 mg/kg); (D) BHT + ELL (500 mg/kg); (E) BHT + ELL (1000 mg/kg).

by the histopathological observation. These results conclude that the protective effect of ELL against acute BHT-induced oxidative stress in rats could be through the upregulation of antioxidant enzymes.

\section{References}

Aebi, H., 1984. Catalase in vitro. Methods in Enzymology 105, 121-126. Bartus, M., Lomnicka, M., Lorkowska, B., Franczyk, M., Kostogrys, R.B., Pisulewski, P.M., Chlopicki, S., 2005. Hypertriglyceridemia but not hypercholesterolemia induces endothelial dysfunction in the rat. Pharmacology Reports 57, 127-137.

Beauchamp, C., Fridovich, I., 1971. Superoxid dismutase: improved assays and an assay applicable to acrylamide gels. Analytical Biochemistry 44, 276-287.

Cerutti, P.A., 1985. Prooxidant states and tumor promotion. Science 227, 375-381.

Chang, W.S., Chang, Y.H., Lu, F.J., Chiang, H.C., 1994. Inhibitory effects of phenolics on xanthine oxidase. Anticancer Research 14, 501-506.

Erdem, A., Gundogan, N.U., Usubutun, A., Kilinc, K., Erdem, S.R., Kara, A., Bozkurt, A., 2000. The protective effect of taurine against gentamicin- induced acute tubular necrosis in rats. Nephrology Dialysis Transplantation $15,1175-1182$

Flohe, L., Gunzler, W.F., 1984. Assays of glutathione peroxidase. Methods in Enzymology 105, 114-121.

Hassan, H.M., 1988. Biosynthesis and regulation of superoxide dismutases. Free Radical Biology and Medicine 5, 377-385.

He, Z.D., Dong, H., Xu, H.X., Ye, W.C., Sun, H.D., But, P.P.H., 2001a. Secoiridoid constituents from the fruits of Ligustrum lucidum. Phytochemistry 56, 327-330

He, Z.D., But, P.P.H., Chan, T.W., Dong, H., Xu, H.X., Lau, C.P., Sun, H.D., 2001b. Antioxidative glucosides from the fruits of Ligustrum lucidum. Chemical and Pharmaceutical Bulletin 49, 780-784.

Hickey, E.J., Raje, R.R., Reid, V.E., Gross, S.M., Ray, S.D., 2001. Diclofenac induced in vivo nephrotoxicity may involve oxidative stress-mediated massive genomic DNA fragmentation and apoptotic cell death. Free Radical Biology and Medicine 31, 139-152.

Jung, C.H., Seog, H.M., Choi, I.W., Choi, H.D., Cho, H.Y., 2005. Effects of wild ginseng (Panax ginseng C.A. Meyer) leaves on lipid peroxidation levels and antioxidant enzyme activities in streptozotocin diabetic rats. Journal of Ethnopharmacology 98, 245-250.

Lanigan, R.S., Yamarik, T.A., 2002. Final report on the safety assessment of BHT (1). International Journal of Toxicology 21, 19-94. 
Lavrovsky, Y., Chatterjee, B., Clark, R.A., Roy, A.K., 2000. Role of redoxregulated transcription factors in inflammation, aging and age-related diseases. Experimental Gerontology 35, 521-532.

Liu, H., Shi, Y., Wang, D., Yang, G., Yu, A., Zhang, H., 2003. MECC determination of oleanolic acid and ursolic acid isomers in Ligustrum lucidum Ait. Journal of Pharmaceutical and Biomedical Analysis 32, 479-485.

Lowry, O.H., Rosebrough, N.J., Farr, A.L., Randall, R.J., 1951. Protein measurement with the folin phenol reagent. Journal of Biological Chemistry 193, 265-275.

Ma, S.C., He, Z.D., Deng, X.L., But, P.P.H., Ooi, V.E.C., Xu, H.X., Lee, S.H.S., Lee, S.F., 2001. In vitro evaluation of secoiridoid glucosides from the fruits of Ligustrum lucidum as antiviral agents. Chemical and Pharmaceutical Bulletin 49, 1471-1473.

Marino, A.A., Mitchell, J.T., 1972. Lung damage in mice following intraperitoneal injection of butylated hydroxytoluene. In: Proceedings of the Society for Experimental Biology and Medicine, vol. 140, pp. 122-125.

McCord, J.M., Fridovich, I., 1969. Superoxide dismutase: an enzymic function for erythrocuprein (hemocaprein). Journal of Biological Chemistry 244, 6049-6055.

Mizutani, T., Nomura, H., Yamamoto, K., Tajima, K., 1984. Modification of butylated hydroxytoluene-induced pulmonary toxicity in mice by diethyl maleate, buthionine sulfoximine, and cysteine. Toxicolology Letters 23, 327-331.

Nakagawa, Y., Tayama, K., Nakao, T., Hiraga, K., 1984. On the mechanism of butylated hydroxytoluene-induced hepatic toxicity in rats. Biochemical Pharmacology 33, 2669-2674.

Oh, P.S., Lee, S.L., Lim, K.T., 2006. Hypolipidemic and antioxidative effects of the plant glycoprotein (36 kDa) from Rhus verniciflua stokes fruit in Triton WR-1339-induced hyperlipidemic mice. Bioscience, Biotechnology and Biochemistry 70, 447-456.

Ohkawa, H., Ohishi, N., Yagi, K., 1979. Assay for lipid peroxides in animal tissue by thiobarbituric acid reaction. Analytical Biochemistry 95, 351-358.
Powell, C.J., Connolly, A.K., 1991. The site specificity and sensitivity of the rat liver to butylated hydroxytoluene-induced damage. Toxicology and Applied Pharmacology 108, 67-77.

Rajasekaran, S., Sivagnanam, K., Subramanian, S., 2005. Antioxidant effect of Aloe vera gel extract in streptozotocin-induced diabetes in rats. Pharmacology Reports 57, 90-96.

Rajesh, M.G., Latha, M.S., 2004. Preliminary evaluation of the antihepatotoxic activity of Kamilari, a polyherbal formulation. Journal of Ethnopharmacology $91,99-104$.

Reed, M., Fujiwara, H., Thompson, D.C., 2001. Comparative metabolism, covalent binding and toxicity of BHT congeners in rat liver slices. ChemicoBiological Interactions 138, 155-170.

Selvakumar, E., Prahalathan, C., Mythili, Y., Varalakshmi, P., 2004. Protective effect of dl-alpha-lipoic acid in cyclophosphamide induced oxidative injury in rat testis. Reproductive Toxicology 19, 163-167.

Shi, L., Ma, Y., Cai, Z., 1998. Quantitative determination of salidroside and specnuezhenide in the fruits of Ligustrum lucidum Ait. by high performance liquid chromatography. Biomedical Chromatography 12, 27-30.

Sun, Y., Dwyer-Nield, L.D., Malkinson, A.M., Zhang, Y.L., Thompson, J.A., 2003. Responses of tumorigenic and non-tumorigenic mouse lung epithelial cell lines to electrophilic metabolites of the tumor promoter butylated hydroxytoluene. Chemico-Biological Interactions 145, 41-51.

Witschi, H., Malkinson, A.M., Thompson, J.A., 1989. Metabolism and pulmonary toxicity of butylated hydroxytoluene (BHT). Pharmacology and Therapeutics 42, 89-113.

Yanardag, R., Tunali, S., 2006. Vanadyl sulfate administration protects the streptozotocin-induced oxidative damage to brain tissue in rats. Molecular and Cellular Biochemistry 286, 153-159.

Yim, T.K., Wu, W.K., Pak, W.F., Ko, K.M., 2001. Hepatoprotective action of an oleanolic acid-enriched extract of Ligustrum lucidum fruits is mediated through an enhancement on hepatic glutathione regeneration capacity in mice. Phytotherapy Research 15, 589-592. 